\title{
PERANCANGAN SISTEM INFORMASI PENGELOLAAN PERSEDIAAN BAHAN BAKU DI OUTLET PERUSAHAAN XYZ
}

\section{DESIGNING RAW MATERIAL INVENTORY MANAGEMENT SYSTEM IN THE OUTLET OF XYZ COMPANY}

\author{
Raihan Ahmad Fadhil $1^{1 *}$, A.A.N. Perwira Redi $2^{2)}$, Mirna Lusiani $3^{3)}$ \\ 1,3) Universitas Pertamina, DKI Jakarta, Indonesia \\ 2) Industrial Engineering Department, BINUS Graduate Program - Master of Industrial Engineering, Bina Nusantara University, Jakarta \\ 11480 , Indonesia
}

\section{ARTICLE INFORMATION \\ Article history: \\ Received: September 29, 20 \\ Revised: November 04, 20 \\ Accepted: November 26, 20}

Keywords:

Inventory Management

Information System

Min-Max Stock

Waterfall Model

Kata kunci:

Pengelolaan Persediaan

Sistem Informasi

Min-Max Stock

Model Waterfall
${ }^{*}$ Corresponding Author

Raihan Ahmad Fadhil

E-mail: raihanahmadfadhil@gmail.com

\section{$A B S T R A C T$}

This research is about design and implementation of information systems in PT XYZ Outlet. The goal is to design and implement an information system that can manage data and inventory management in an integrated and centralized manner. In designing the information system, the Waterfall model is used which has the advantages that have been considered, one of which is conformity to the characteristics of the problems found. Inventory management problems in this study solved using the Min-Max Stock method. The application of the Min-Max Stock method is effective and can reduce inventory costs at PT XYZ. For Chicken Boneless Marinated, Beef Santori Tenderloin, and Coffee Bean items each reduce $5 \%$ or IDR $1,610,000,7 \%$ or IDR $1,598,031,648$, and $11 \%$ or IDR $2,150,000$. The results of the design and implementation of this information system can assist in recording and managing inventory that is integrated and centralized.

\section{A B S T R A K}

Penelitian ini membahas mengenai proses perancangan dan implementasi sistem informasi pada Outlet PT XYZ. Tujuan penelitian ini adalah memperoleh rancangan dan mengimplementasikan suatu sistem informasi yang mengintegrasikan dan memusatkan pengelolaan pencatatan serta pengelolaan persediaan. Model Waterfall digunakan untuk pengembangan sistem informasi dalam penelitian ini karena memiliki kelebihan-kelebihan yang telah dipertimbangkan, salah satunya adalah kesesuaian dengan karakterisik permasalahan yang ditemukan. Sedangkan metode pengelolaan persediaan yang digunakan dalam penelitian ini adalah metode Min-Max Stock. Penerapan Min-Max Stock sebagai metode pengelolaan persediaan efektif untuk diterapkan dan dapat memangkas biaya persediaan di PT XYZ. Untuk barang Chicken Boneless Marinasi, Beef Santori Tenderloin, dan Coffee Bean masing-masing menghasilkan penghematan sebesar 5\% atau Rp 1.610.000, 7\% atau Rp 1.598.031,648, dan $11 \%$ atau Rp 2.150 .000 . Hasil dari perancangan dan implementasi sistem informasi ini dapat membantu PT XYZ dalam melakukan proses pencatatan dan pengelolaan persediaan yang terintegrasi dan terpusat.

This is an open access article under the $\mathrm{CC}-\mathrm{BY}$ license.

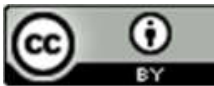




\section{PENDAHULUAN}

Sektor ekonomi kreatif di Indonesia terus mengalami perkembangan setiap tahun. Hal tersebut dapat dibuktikan dengan melihat kontribusi ekonomi kreatif terhadap Produk Domestik Bruto (PDB). Data Badan Ekonomi Kreatif pada Gambar 1 menunjukkan peningkatan kontribusi ekonomi kreatif terhadap PDB pada tahun 2010-2016 [1]. Berdasarkan data tersebut ekonomi kreatif berkontribusi sebesar 7,44\% atau 922,59 triliun rupiah dari total PDB pada tahun 2016.

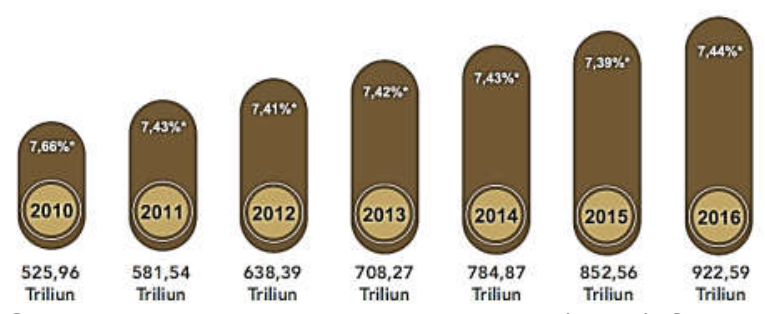

Gambar 1. Produk Domestik Bruto (PDB) Sektor Ekonomi Kreatif (Badan Ekonomi Kreatif, 2018)

Sektor ekonomi kreatif memiliki berbagai subsektor yang berkontribusi di dalamnya, dan yang memiliki kontribusi terbesar dalam ekonomi kreatif Indonesia adalah kuliner. Subsektor kuliner memberikan kontribusi sebesar $41,4 \%$ dari seluruh kontribusi ekonomi kreatif terhadap PDB, atau lebih dari 381,95 triliun rupiah [1]. Serta $47,21 \%$ penyerapan tenaga kerja atau lebih dari 7.983.064 bekerja pada subsektor kuliner.

Penjelasan tersebut menggambarkan bahwa kuliner merupakan salah satu bisnis yang memiliki potensi besar dan berkontribusi besar bagi perekonomian negara. PT XYZ merupakan salah perusahaan yang berfokus pada bisnis kuliner. Perusahaan ini berdiri pada tahun 2013 dan terus berkembang. Saat ini PT XYZ mempunyai 4 (empat) Outlet restoran yang berada di wilayah Bali, dan 1 (satu) Central Kitchen yang berfungsi sebagai tempat penyimpanan persediaan bahan baku.

Tantangan yang dihadapi dalam mengelola bisnis kuliner cukup besar, contohnya dalam mengelola persediaan bahan baku makanan dan minuman. Keputusan yang diambil mengenai persediaan menjadi sangat penting karena memiliki pengaruh besar terhadap keuntungan dan kerugian perusahaan. Permasalahan yang juga dihadapi PT $X Y Z$ adalah permasalahan pengelolaan persediaan. PT XYZ kerap menghadapi kehabisan dan kelebihan persediaan barang. Kesalahan dalam melakukan estimasi dapat menyebabkan kerugian ketika tingkat persediaan berlebih (overstock) hingga tidak terpakai, serta kerugian ketika terjadi kekurangan persediaan (stockout) dan tidak dapat memenuhi permintaan pelanggan [2].

Pengelolaan persediaan dapat diimplementasikan untuk menentukan nilai persediaan yang lebih akurat, sehingga dapat meminimasi kerugian perusahaan. Metode pengelolaan persediaan yang dapat digunakan salah satunya yaitu metode Min-Max Stock. Metode ini membantu mengelola persediaan dengan memberikan informasi jumlah barang minimal dan maksimal yang harus disimpan untuk menjaga ketersediaan barang. Metode Min-Max bekerja dengan memberi batas maksimal dan minimal nilai persediaan yang diizinkan untuk disimpan di dalam gudang [3]. Metode ini digunakan karena data permintaan di PT XYZ bersifat fluktuatif, namun tidak terlalu signifikan.

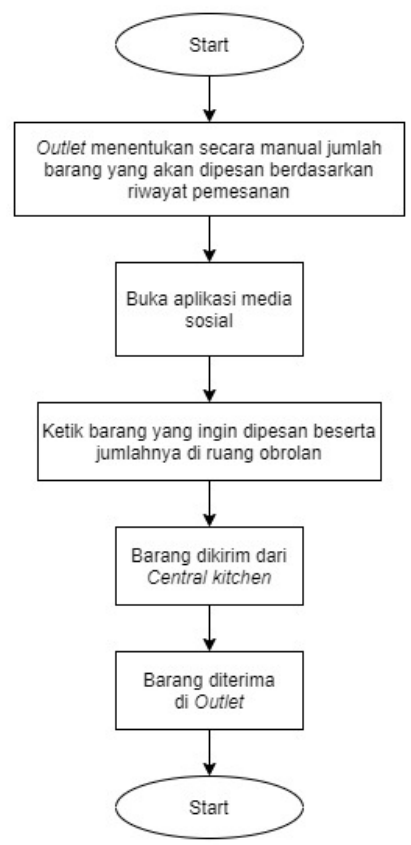

Gambar 2. Proses Purchase Order

Data-data sebagai input dalam melakukan pengelolaan persediaan sangat dibutuhkan. Dalam melakukan pengelolaan persediaan dibutuhkan data internal perusahaan seperti POS (Point of Sales) dan data eksternal seperti cuaca, kejadian, dan lain-lain [4]. Namun PT XYZ saat ini belum mempunyai sistem pencatatan yang baik, proses pencatatan secara manual masih dilakukan seperti pada Gambar 2 sehingga tidak ada integrasi data antara Outlet dengan Central Kitchen. Sehingga ketidaksesuaian antara data yang tercatat dengan keadaan yang sebenarnya seringkali terjadi. Salah satu cara untuk meningkatkan kualitas pencatatan suatu sistem informasi adalah dengan Sistem Informasi. 
Melakukan perancangan dan pengembangan Sistem Informasi dapat meningkatkan kualitas sistem pencatatan menjadi lebih terorganisir, sistematis dan lebih akurat [5] [6]. Penelitian mengenai pengembangan Sistem Informasi dan penerapan Metode Min-Max Stock secara terpisah telah banyak dilakukan sebelumnya. Dalam penelitian ini dikombinasikan penerapan Sistem Informasi pencatatan yang terintegrasi dan terpusat dengan pengelolaan persediaan menggunakan metode Min-Max Stock di PT XYZ.

Berdasarkan penjelasan tersebut maka dibutuhkan suatu pengelolaan persediaan dengan menggunakan metode Min-Max Stock untuk menanggulangi permasalahan persediaan di PT $X Y Z$. Namun pengelolaan persediaan tersebut akan berjalan dengan baik jika data-data yang digunakan untuk perhitungan persediaan adalah data yang akurat. Oleh karena itu dibutuhkan juga sistem pencatatan yang terintegrasi dan terpusat antara Outlet dan Central Kitchen PT XYZ. Dengan begitu proses pengelolaan persediaan akan lebih mudah dan efektif, karena data-data pendukung yang dibutuhkan akan lebih tepat dan akurat. Berdasarkan penjelasan tersebut maka judul penelitian ini adalah Analisis Perancangan Sistem Informasi Pengelolaan Persediaan Bahan Baku di Outlet PT XYZ.

\subsection{Tinjauan Pustaka}

Penelitian yang dilakukan oleh Kinanthi et al berhasil menghemat biaya persediaan sebesar Rp 700.000 untuk setiap periode [7]. Dalam penelitian tersebut, metode Min-Max Stock diaplikasikan untuk bahan baku tembakau di PT. Djitoe Indonesia Tobacco. Dengan metode yang sama Yedida dan Ulkhaq dapat menghemat biaya persediaan sebesar Rp 22.863.000 untuk persediaan bahan baku di CV Endhigra Prima [8]. Penelitian Putri dan Ulkhaq yang dilakukan di PT Jaya Aflaha juga berhasil menghemat biaya sebesar Rp 1.515.508,99 dengan menerapkan Metode Min-Max Stock [3].

Berikut pembahasan penelitian sebelumnya tentang pengembangan sistem informasi. Penelitian yang dikerjakan oleh Perkasa et al adalah merancang sistem informasi manajemen restoran [9]. Model pengembangan sistem yang digunakan dalam penelitian tersebut adalah model Waterfall. Sistem informasi dikembangkan untuk mempermudah dalam mengelola aktivitas pemesanan, memproses pesanan, pembuatan invoice, dan laporan restoran. Pengembangan sistem informasi juga dikerjakan oleh Sayuti et al yang digunakan untuk membantu mengelola kegiatan akademik di sekolah menengah [10].
Sistem informasi dalam penelitian tersebut diterapkan untuk proses registrasi siswa baru dan penilaian hasil belajar siswa. Model waterfall diterapkan dalam penelitian tersebut.

Palit et al mengerjakan penelitian lain tentang perancangan sistem informasi berbasis web untuk keuangan Gereja [6]. Model waterfall digunakan dalam penelitian tersebut. Sistem informasi dibangun untuk membantu memproses dan menghasilkan laporan keuangan Gereja. Hasil yang didapatkan dalam penelitian ini adalah sistem informasi yang dapat mempermudah dalam pengelolaan dan pelaporan keuangan Gereja dan menghasilkan data yang lebih akurat.

Berdasarkan penjelasan di atas, penelitian ini akan menggunakan Metode Min-Max Stock untuk pengelolaan persediaan, dan menggunakan Model Waterfall untuk merancang dan mengimplementasikan sistem informasi.

\section{METODE PENELITIAN}

Jenis penelitian ini adalah applied research, yaitu penelitian yang didasari atas analisis terhadap permasalahan yang terjadi serta memberikan suatu solusi dari permasalahan tersebut yang dapat diterapkan. Adapun dalam teknik pengumpulan data pada penelitian ini menggunakan 3 (tiga) jenis teknik pengumpulan data, yaitu wawancara, observasi, dan studi literatur. Wawancara dilakukan dengan Admin Central Kitchen PT XYZ yaitu Ibu Ni Wayan Santy Asih. Sedangkan observasi dilakukan dengan mengamati proses yang terjadi saat pembuatan Purchase Order dan kendala-kendala yang terjadi saat proses tersebut. Dan studi literatur dilakukan untuk mencari dasar dari teori-teori yang dibutuhkan pada penelitian ini, serta meninjau penelitian-penelitian sejenis yang telah dilakukan sebelumnya.

Ruang lingkup pada penelitian ini berguna untuk memberi batasan agar penelitian terarah dan terukur. Adapun batasan-batasan yang ditentukan adalah sebagai berikut.

1. Leadtime yang digunakan untuk perhitungan pengelolaan persediaan yaitu 2 hari.

2. Sistem yang akan dibangun berbasis web, sehingga dapat diakses melalui browser.

3. Sistem informasi digunakan untuk 4 (empat) Outlet PT XYZ dan 1 (satu) Central Kitchen.

4. Biaya perangkat yang digunakan tidak diperhitungkan dalam penelitian ini.

5. Hardware yang digunakan memiliki processor Intel(R) Core(TM) i3-4030U CPU @ 1.90 Ghz (4CPUs), 1.9 Ghz, memory 10240 MB RAM, harddisk $500 \mathrm{~GB}$. 
6. Software yang digunakan adalah sistem operasi Windows 10 Pro 64-bit.

7. Bahasa pemrograman yang digunakan adalah PHP, HTML, CSS, Javascript.

8. Framework yang digunakan untuk pengembangan sistem informasi adalah framework Codeigniter.

\subsection{Min-Max Stock}

Metode Min-Max bekerja dengan cara memberi batas maksimal dan minimal nilai persediaan yang diperbolehkan untuk disimpan di gudang [3]. Adapun tahapan-tahapan dalam menerapan metode Min-Max Stock adalah sebagai berikut [8].

1. Menghitung nilai Persediaan Pengaman (Safety Stock). Persediaan pengaman merupakan persediaan tambahan yang perlu ditambahkan untuk menjaga ketersediaan barang ketika terjadi lonjakan permintaan atau keterlambatan barang datang.

2. Menghitung nilai Persediaan Minimum (Minimum Stock). Persediaan minimum merupakan jumlah pemakaian barang selama rentang waktu pesanan pembelian yang dihitung dengan perkalian antara waktu pesanan per periode dan rata-rata pemakaian dalam satu bulan/minggu/hari ditambah dengan persediaan pengaman.

3. Menghitung nilai Persediaan Maksimal (Maximum Stock). Persediaan maksimal merupakan jumlah persediaan maksimal yang diizinkan disimpan dalam persediaan.

4. Jumlah barang yang perlu dipesan untuk pengisian kembali persediaan.

\subsection{Model Waterfall}

Model Waterfall adalah salah satu model pengembangan sistem informasi yang biasa digunakan oleh pengembang, Gambar 3 adalah gambaran dari model Waterfall. Model Waterfall berfokus kepada suatu proses perencanaan yang matang sebelum melakukan pengembangan sistem informasi [11]. Berikut ini langkah-langkah yang harus dilakukan secara berurutan untuk menerapkan model Waterfall [12].

1. Requirement

Tahap ini menjelaskan deskripsi atau kebutuhan dari perilaku yang berjalan di perusahaan yang akan dijadikan dasar atau acuan dalam pengembangan sistem informasi.

2. High Level Design

Berdasarkan dari evaluasi seluruh informasi yang didapat maka selanjutnya merumuskan gambaran yang sesuai untuk diterapkan dalam sistem informasi yang akan dikembangkan.

3. Coding
Tahap ini mulai mengimplementasikan rancangan yang diperoleh pada tahap requirement dan high level design, dan memulai proses kode program.

4. Testing

Tahap ini dilakukan pengecekan sistem informasi yang telah dibangun, telah sesuai atau tidak sesuai dengan requirement dan high level design yang telah dirancang. Serta dilakukan pengecekan terhadap kelancaran sistem informasi ketika digunakan.

5. Maintenance

Sistem informasi yang telah digunakan dan diterapkan dalam sistem akan membutuhkan suatu perbaikan, modifikasi, atau penambahan.

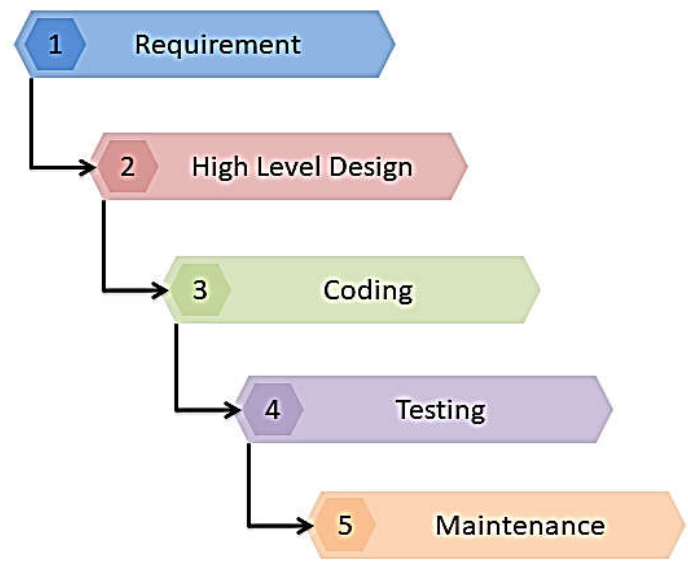

Gambar 3. Model Waterfall

Kelebihan Model Waterfall dibandingkan dengan model-model pengembangan sistem lainnya adalah sebagai berikut [12].

1. Mudah untuk dimengerti dan diterapkan.

2. Telah banyak diterapkan dan diketahui oleh para pengembang sistem informasi.

3. Sesuai jika diterapkan untuk sistem yang telah berjalan dengan matang.

4. Setiap tahapan dilakukan dan diselesaikan satu persatu secara berurutan.

\section{HASIL DAN PEMBAHASAN}

\subsection{Perhitungan Min-Max Stock}

Penerapan metode Min-Max Stock dalam sistem informasi pengelolaan persediaan di Outlet PT $\mathrm{XYZ}$ beserta contoh perhitungannya akan dijelaskan pada bagian ini. Perhitungan dilakukan menggunakan 3 (tiga) barang dengan pengeluaran terbesar seperti yang dapat dilihat pada Tabel 1. Dan data historis bulan Desember 2019 hingga Februari 2020 dari Outlet Merdeka digunakan dalam contoh perhitungan. Asumsiasumsi yang digunakan dalam perhitungan MinMax Stock adalah sebagai berikut. 
1. Leadtime yang digunakan yaitu 2 hari.

2. Harga Barang Beef Santori Tenderloin yaitu Rp 32.000 per Pcs.

3. Harga Barang Chicken Boneless Marinasi yaitu $\mathrm{Rp} 60.000$ per $\mathrm{Kg}$.

4. Harga Barang Coffee Bean yaitu Rp 200.000 per $\mathrm{Kg}$

5. Biaya Pesan dan Biaya Simpan untuk barang Beef Santori Tenderloin dan Chicken Boneless Marinasi diperoleh dari penelitian yang dilakukan oleh Bora and Nugroho [13]. Pada penelitian tersebut terdapat Biaya Pesan dan Biaya Simpan untuk barang Daging Ayam yang memiliki karakteristik yang sama dengan barang Beef Santori Tenderloin dan Chicken Boneless Marinasi. Biaya Pesan yaitu Rp 35.000 per sekali pesan, sedangkan Biaya Simpan yaitu 10\% dari harga barang.

6. Biaya Pesan dan Biaya Simpan untuk Coffee Bean juga diperoleh dari penelitian yang dilakukan oleh Bora and Nugroho [13]. Pada penelitian tersebut terdapat Biaya Pesan dan Biaya Simpan untuk barang Beras yang memiliki karakteristik yang sama dengan Coffee Bean. Biaya Pesan yaitu Rp 50.000 per sekali pesan, sedangkan Biaya Simpan yaitu $5 \%$ dari harga barang.

Tabel 1 Barang dengan Pengeluaran Terbesar

\begin{tabular}{llll}
\hline Barang & $\begin{array}{l}\text { Desember } \\
\mathbf{2 0 1 9} \\
\text { (Rp1000) }\end{array}$ & $\begin{array}{l}\text { Januari } \\
\mathbf{2 0 2 0} \\
(\mathbf{R p 1 0 0 0 )})\end{array}$ & $\begin{array}{l}\text { Februari } \\
\mathbf{2 0 2 0} \\
\mathbf{( R p 1 0 0 0 )}\end{array}$ \\
\hline $\begin{array}{l}\text { Beef } \\
\text { Santori } \\
\begin{array}{l}\text { Tenderloin } \\
\text { Chicken }\end{array}\end{array}$ & 27.680 & 28.480 & 26.432 \\
$\begin{array}{l}\text { Boneless } \\
\text { Marinasi }\end{array}$ & 69.252 & 43.752 & 35.934 \\
$\begin{array}{l}\text { Coffee } \\
\text { Bean }\end{array}$ & 22.350 & 18.050 & 15.400 \\
\hline
\end{tabular}

Tabel 2 Data Kebutuhan Makmimal dan Rata-

Rata Kebutuhan

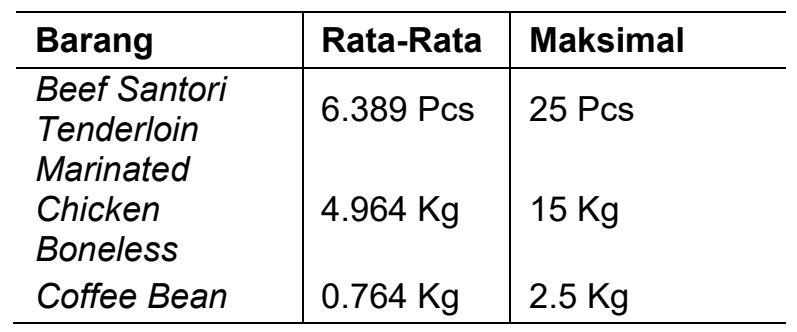

Tabel 2 adalah data rata-rata kebutuhan dan kebutuhan Maksimal berdasarkan hasil pengolahan data historis bulan Desember 2019 hingga Februari 2020 pada Outlet Merdeka. Datadata pada Tabel 2 akan digunakan sebagai input dalam contoh perhitungan dengan metode MinMax Stock.

\section{Contoh Perhitungan untuk Beef Santori Tenderloin}
Safety Stock $=($ Pemakaian Maksimal - Ratarata Kebutuhan) $\times$ Lead Time

Safety Stock $=(25-6,389) \times 2$

Safety Stock $=37,222$ Pcs

Minimum Stock $=($ Ratarata Kebutuhan $\times$ Lead Time $)+$ Safety Stock

Minimum Stock $=(6,389 \times 2)+37,222$

Minimum Stock $=50$ Pcs

Maximum Stock $=2 \times$ (Ratarata Kebutuhan $\times$ Lead Time $)+$ Safety Stock

Maximum Stock $=2 \times(6,389 \times 2)+37,222$

Maximum Stock $=62,778$ Pcs

Tingkat Pemesanan Kembali $(Q)=$ Maximum Minimum

Tingkat Pemesanan Kembali $(Q)=62,778-50$

Tingkat Pemesanan Kembali $(Q)=12,778$ Pcs

Berdasarkan perhitungan diatas, Persediaan Pengaman (Safety Stock) ditambah 37.222 Pcs atau 38 Pcs untuk menjaga ketersediaan barang, Minimum Stock yang perlu tersedia adalah 50 Pcs, Maximum Stock yang dapat tersimpan di gudang 62.778 Pcs atau 63 Pcs, dan Jumlah Pesanan untuk mengisi ulang persediaan adalah 12.778 Pcs atau 13 Pcs.

\section{Contoh perhitungan untuk Chicken Boneless Marinasi}
Safety Stock $=($ Pemakaian Maksimal - Ratarata Kebutuhan) $\times$ Lead Time

Safety Stock $=(15-4,964) \times 2$

Safety Stock $=20,071 \mathrm{Kg}$

Minimum Stock $=($ Ratarata Kebutuhan $\times$ Lead Time) + Safety Stock

Minimum Stock $=(4,964 \times 2)+20,071$

Minimum Stock $=30 \mathrm{Kg}$

Maximum Stock $=2 \times$ (Ratarata Kebutuhan $\times$ Lead Time $)+$ Safety Stock

Maximum Stock $=2 \times(4,964 \times 2)+20,071$

Maximum Stock $=39,929 \mathrm{Kg}$ 

Tingkat Pemesanan Kembali $(Q)=\begin{array}{r}\text { Maximum }- \\ \text { Minimum }\end{array}$

Tingkat Pemesanan Kembali $(Q)=39,929-30$ Tingkat Pemesanan Kembali $(Q)=9,929 \mathrm{Kg}$

Berdasarkan perhitungan di atas, Persediaan Pengaman (Safety Stock) ditambah $20,071 \mathrm{Kg}$ untuk menjaga ketersediaan barang, Minimum Stock yang perlu tersedia $30 \mathrm{Kg}$, Maximum Stock yang disimpan di gudang $39.929 \mathrm{Kg}$, dan Jumlah Pesanan untuk mengisi kembali persediaan adalah $9,929 \mathrm{Kg}$.

\section{Contoh perhitungan untuk Coffee Bean}

$$
\begin{aligned}
\text { Safety Stock }= & (\text { Pemakaian Maksimal }- \\
& \text { Ratarata Kebutuhan }) \times \\
& \text { Lead Time } \\
\text { Safety Stock }= & (2,5-0,764) \times 2 \\
\text { Safety Stock }= & 3,472 \mathrm{Kg}
\end{aligned}
$$

$$
\begin{aligned}
\text { Minimum Stock }= & (\text { Ratarata Kebutuhan } \times \\
& \text { Lead Time })+ \text { Safety Stock } \\
\text { Minimum Stock }= & (0,764 \times 2)+3,472 \\
\text { Minimum Stock }= & 5 \mathrm{Kg} \\
\text { Maximum Stock }= & 2 \times(\text { Ratarata Kebutuhan } \times \\
& \text { Lead Time })+ \text { Safety Stock } \\
\text { Maximum Stock }= & 2 \times(0,764 \times 2)+3,472 \\
\text { Maximum Stock }= & 6,528 \mathrm{Kg}
\end{aligned}
$$

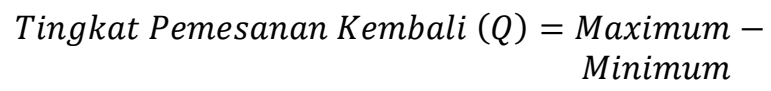

Tingkat Pemesanan Kembali $(Q)=6,528-5$

Tingkat Pemesanan Kembali $(Q)=1,528 \mathrm{Kg}$

Berdasarkan perhitungan diatas, Persediaan Pengaman (Safety Stock) ditambah $3,472 \mathrm{Kg}$ untuk menjaga ketersediaan barang, Minimum

\begin{tabular}{|c|c|c|c|c|c|}
\hline Barang & $\begin{array}{l}\text { Safety } \\
\text { Stock }\end{array}$ & $\begin{array}{l}\text { Min } \\
\text { Stock }\end{array}$ & $\begin{array}{l}\text { Max } \\
\text { Stock }\end{array}$ & $\boldsymbol{Q}$ & $\begin{array}{l}\text { Order } \\
\text { Frequency }\end{array}$ \\
\hline $\begin{array}{l}\text { Marinated } \\
\text { Chicken } \\
\text { Boneless }\end{array}$ & $\begin{array}{l}20,071 \\
\mathrm{Kg}\end{array}$ & $\begin{array}{l}30 \\
\mathrm{Kg}\end{array}$ & $\begin{array}{l}39,929 \\
\mathrm{Kg}\end{array}$ & $\begin{array}{l}9,929 \\
\mathrm{Kg}\end{array}$ & 45 \\
\hline $\begin{array}{l}\text { Beef } \\
\text { Santori } \\
\text { Tenderloin }\end{array}$ & $\begin{array}{l}37,222 \\
\text { Pcs }\end{array}$ & $\begin{array}{l}50 \\
\text { Pcs }\end{array}$ & $\begin{array}{l}62,778 \\
\text { Pcs }\end{array}$ & $\begin{array}{l}12,77 \\
8 \text { Pcs }\end{array}$ & 45 \\
\hline $\begin{array}{l}\text { Coffee } \\
\text { Bean }\end{array}$ & $\begin{array}{l}3,472 \\
\mathrm{Kg}\end{array}$ & $5 \mathrm{Kg}$ & $\begin{array}{l}6,528 \\
\mathrm{Kg}\end{array}$ & $\begin{array}{l}1,528 \\
\mathrm{Kg}\end{array}$ & 45 \\
\hline
\end{tabular}
Stock yang perlu tersedia adalah $5 \mathrm{Kg}$, Maximum Stock yang diizinkan untuk disimpan di gudang $6,528 \mathrm{Kg}$, dan Jumlah Pesanan untuk mengisi ulang persediaan adalah $1,528 \mathrm{Kg}$.

\subsection{Perhitungan Biaya Persediaan}

Tabel 3 merupakan rekapitulasi dari perhitungan Min-Max Stock. Berdasarkan perhitungan tersebut, maka akan dilakukan perhitungan biaya persediaan serta perbandingan biaya persediaan ketika menggunakan metode Min-Max Stock dengan mekanisme yang dilakukan perusahaan.
Tabel 3 Hasil Perhitungan Min-Max Stock

Tabel 4 Perbandingan Biaya Persediaan untuk Chicken Boneless Marinasi

\begin{tabular}{lll}
\hline Parameter & Min-Max Stock & Perusahaan \\
\hline Safety Stock & $20,071 \mathrm{Kg}$ & 0 \\
Min Stock & $30 \mathrm{Kg}$ & 0 \\
Max Stock & $39,929 \mathrm{Kg}$ & 0 \\
$\begin{array}{l}\text { Order } \\
\text { Quantity (Q) }\end{array}$ & $9,929 \mathrm{Kg}$ & $4,964 \mathrm{Kg}$ \\
$\begin{array}{l}\text { Order } \\
\text { Frequency }\end{array}$ & 45 & 91 \\
$\begin{array}{l}\text { Total Order } \\
\text { and Holding }\end{array}$ & $\mathrm{Rp} 4.255 .800$ & $\mathrm{Rp} 5.865 .800$ \\
$\begin{array}{l}\text { Costs } \\
\begin{array}{l}\text { Total Items } \\
\text { Cost }\end{array}\end{array}$ & $\mathrm{Rp} \mathrm{26.808.000}$ & $\mathrm{Rp} \mathrm{26.808.000}$ \\
$\begin{array}{l}\text { Total } \\
\text { Inventory }\end{array}$ & $\mathrm{Rp} \mathrm{31.063.800}$ & $\mathrm{Rp} 32.673 .800$ \\
Cost & & \\
\hline
\end{tabular}

Perhitungan biaya persediaan pada Tabel 4 menunjukkan terjadinya penghematan biaya persediaan sebesar $5 \%$ atau setara dengan Rp 1.610.000 dengan penerapan metode Min-Max Stock. Hal ini dikarenakan terdapat safety stock sebesar $20,071 \mathrm{Kg}$ dan minimal barang yang harus disimpan sebanyak $30 \mathrm{Kg}$ untuk menjaga persediaan barang tetap terjaga, sehingga frekuensi pemesanan dapat dilakukan lebih sedikit untuk memangkas Biaya Pesan.

Tabel 5 Perbandingan Biaya Persediaan untuk Beef Santori Tenderloin

\begin{tabular}{lll}
\hline Parameter & Min-Max Stock & Perusahaan \\
\hline Safety Stock & 37,222 Pcs & 0 \\
Min Stock & 50 Pcs & 0 \\
Max Stock & 62,778 Pcs & 0 \\
$\begin{array}{l}\text { Order } \\
\text { Quantity (Q) }\end{array}$ & 12,778 Pcs & 6,389 Pcs \\
$\begin{array}{l}\text { Order } \\
\text { Frequency }\end{array}$ & 45 & 63 \\
$\begin{array}{l}\text { Total Order } \\
\text { and Holding }\end{array}$ & $\mathrm{Rp} \mathrm{3.415.000}$ & $\mathrm{Rp} \mathrm{5.013.031,648}$ \\
$\begin{array}{l}\text { Costs } \\
\text { Total Items }\end{array}$ & $\mathrm{Rp} \mathrm{18.400.000}$ & $\mathrm{Rp} \mathrm{18.400.000}$ \\
Cost & &
\end{tabular}




\begin{tabular}{lll}
\hline Parameter & Min-Max Stock & Perusahaan \\
\hline $\begin{array}{l}\text { Total } \\
\text { Inventory } \\
\text { Cost }\end{array}$ & RP 21.815.000 & Rp 23.413.031,65 \\
\hline
\end{tabular}

Perhitungan biaya persediaan pada Tabel 5 menunjukkan terjadinya penghematan biaya persediaan sebesar $7 \%$ atau setara dengan Rp 1.598.031,648 dengan penerapan metode MinMax Stock. Hal ini dikarenakan terdapat safety stock sebesar 37,222 Pcs dan minimal barang yang harus disimpan sebanyak 50 Pcs untuk menjaga persediaan barang tetap terjaga, sehingga frekuensi pemesanan dapat dilakukan lebih sedikit untuk memangkas Biaya Pesan.

Tabel 6 Perbandingan Biaya Persediaan untuk

\section{Coffee Bean}

\begin{tabular}{|c|c|c|}
\hline Parameter & Min-Max Stock & Perusahaan \\
\hline Safety Stock & $3,472 \mathrm{Kg}$ & 0 \\
\hline Min Stock & $5 \mathrm{Kg}$ & 0 \\
\hline Max Stock & $6,528 \mathrm{Kg}$ & 0 \\
\hline $\begin{array}{l}\text { Order } \\
\text { Quantity }(\mathrm{Q})\end{array}$ & $1,528 \mathrm{Kg}$ & $0,764 \mathrm{Kg}$ \\
\hline $\begin{array}{l}\text { Order } \\
\text { Frequency }\end{array}$ & 45 & 88 \\
\hline $\begin{array}{l}\text { Total Order } \\
\text { and Holding } \\
\text { Costs }\end{array}$ & IDR 2.937.500 & IDR 5.087.500 \\
\hline $\begin{array}{ll}\text { Total Items } \\
\text { Cost }\end{array}$ & IDR 13.750.000 & IDR 13.750 .000 \\
\hline $\begin{array}{l}\text { Total } \\
\text { Inventory } \\
\text { Cost }\end{array}$ & IDR 16.687 .500 & IDR 18.837 .500 \\
\hline
\end{tabular}

Perhitungan biaya persediaan pada Tabel 6 menunjukkan terjadinya penghematan biaya persediaan sebesar $11 \%$ atau setara dengan Rp 2.150.000 dengan penerapan metode Min-Max Stock. Hal ini dikarenakan terdapat safety stock sebesar $3,472 \mathrm{Kg}$ dan minimal barang yang harus disimpan sebanyak $5 \mathrm{Kg}$ untuk menjaga persediaan barang tetap terjaga, sehingga frekuensi pemesanan dapat dilakukan lebih sedikit untuk memangkas Biaya Pesan.

\subsection{Perancangan Sistem Informasi}

Berikut ini adalah proses perancangan sistem informasi pengelolaan persediaan.

\section{Requirement}

Requirement adalah fitur yang akan disediakan dalam sistem informasi. Fitur-fitur ini dihasilkan dari analisis berdasarkan wawancara dan observasi sebelumnya dengan pemangku kepentingan perusahaan.

\section{Use Case Diagram}

Gambar 4 adalah Use Case Diagram yang menjelaskan hubungan antara aktor-aktor dengan fitur-fitur yang ada pada sistem informasi. Berdasarkan Gambar 4 Aktor yang dapat mengakses sistem informasi ini dibagi menjadi 3 yaitu Pengguna Central Kitchen, Pengguna Outlet, dan Guest. Guest merupakan pengguna yang tidak memiliki akses ke sistem informasi, sehingga perlu melakukan registrasi sistem informasi terlebih dahulu. Pengguna di Central Kitchen harus login terlebih dahulu untuk dapat mengakses fitur pengelolaan Purchase Order, mengelola Pengguna, mengelola Inventaris, mengelola Invoice, mengelola barang, dan laporan Central Kitchen. Sedangkan pengguna di Outlet perlu melakukan login terlebih dahulu untuk dapat mengakses fitur pengelolaan Purchase Order dan laporan Outlet.

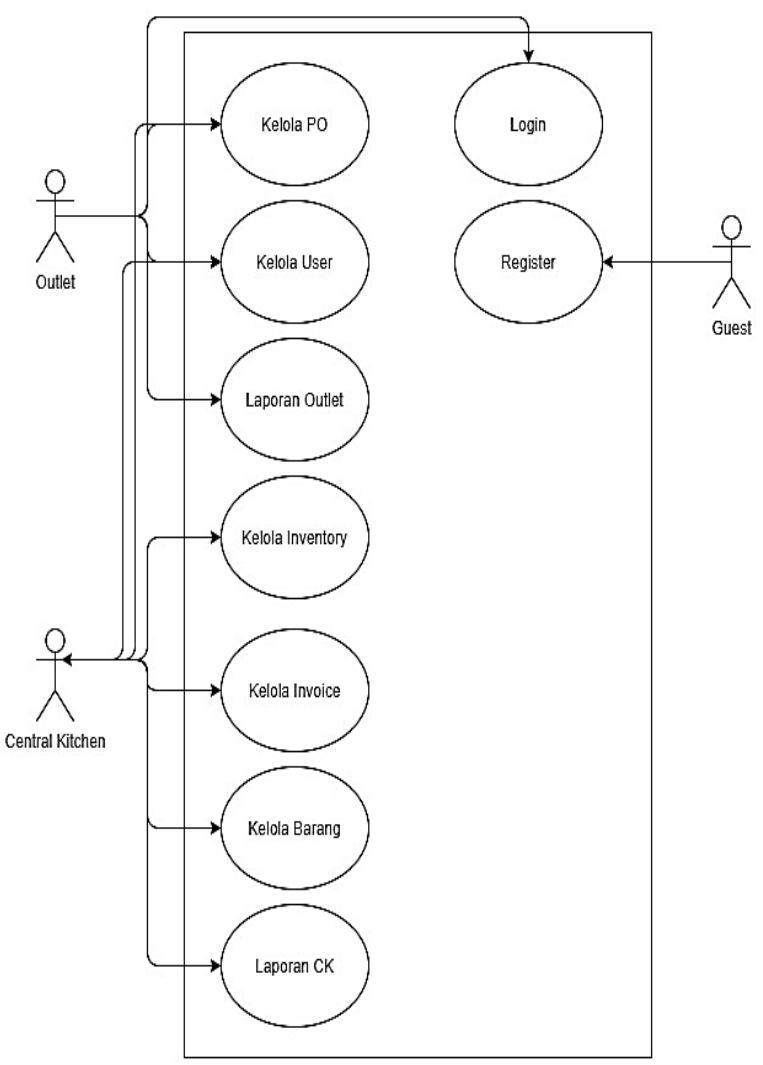

Gambar 4. Use Case Diagram 


\section{Activity Diagram}

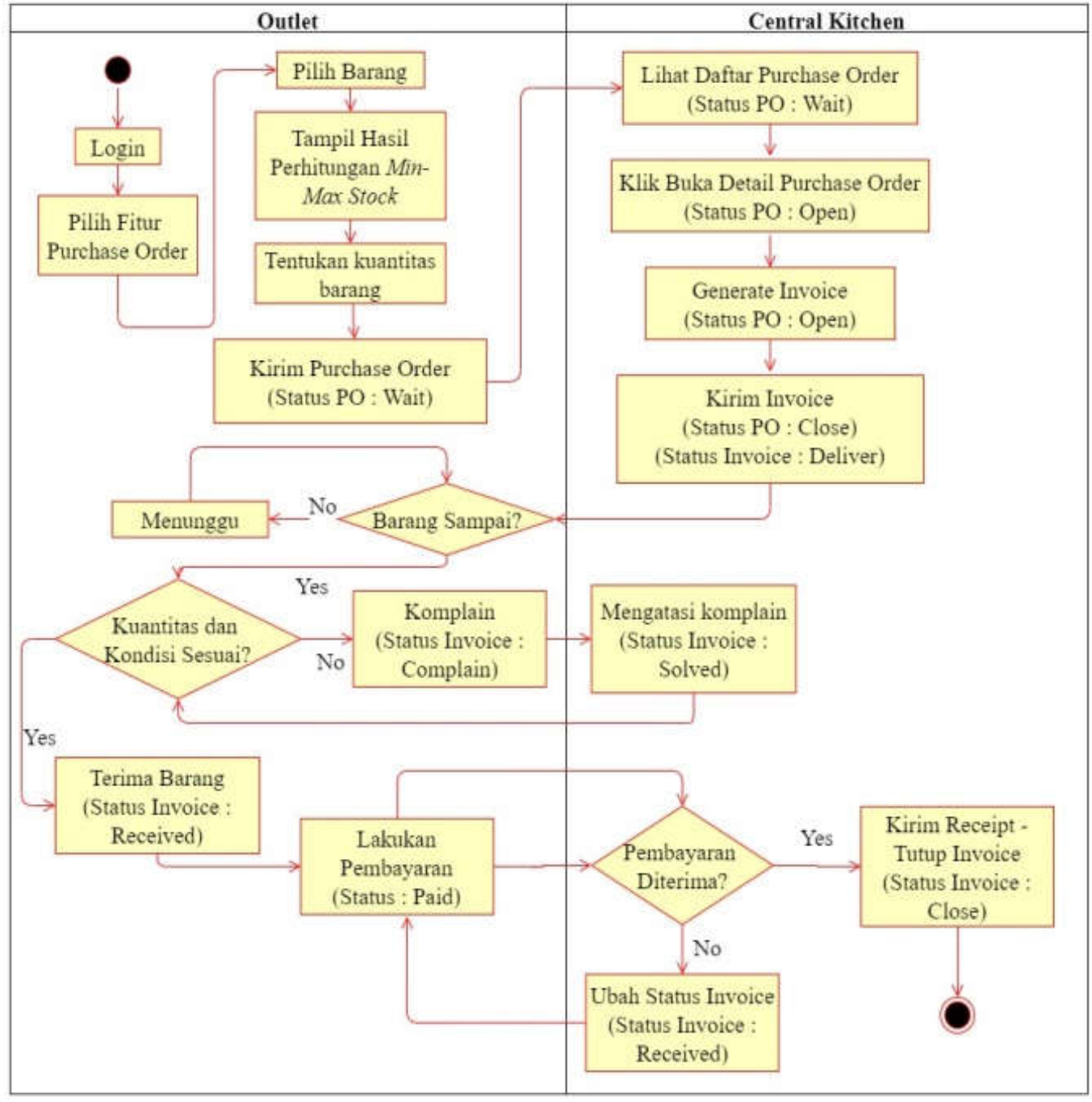

Gambar 5. Activity Diagram

Aktifitas atau proses yang terjadi ketika Outlet melakukan pemesanan barang (Purchase Order) ke Central Kitchen digambarkan dengan Activity Diagram pada Gambar 5. Outlet melakukan Login pada Sistem Informasi, setelah akses berhasil didapat maka selanjutnya pilih fitur Purchase Order. Kemudian akan muncul tampilan pemesanan barang dan dilakukan proses pemilihan barang yang akan dipesan beserta kuantitas yang diminta. Jika pemilihan barang telah dilakukan, Purchase Order dapat dikirim dan status berubah menjadi Wait. Purchase Order yang telah dikirim kemudian akan diterima oleh Central Kitchen, pada bagian ini Central Kitchen akan menerima kumpulan Purchase Order berstatus Wait dan detil setiap Purchase Order dapat dilihat. Purchase Order yang dipilih untuk dibuka oleh Central Kitchen akan berganti status dari Wait menjadi Open yang menandakan pesanan telah diterima oleh Central Kitchen dan akan diproses. Kemudian, Central Kitchen akan mengeluarkan invoice sebagai tanda bukti Purchase Order yang dikirim Outlet sedang diproses. Invoice akan dikirim ke Outlet, hal ini sekaligus menjadi penanda status Purchase Order berubah menjadi Close dan status invoice berubah menjadi Deliver.

Selanjutnya, Central Kitchen akan mengirimkan barang kepada Outlet sesuai dengan Purchase Order yang telah diproses. Outlet akan menunggu barang dikirim dan ketika barang datang akan dilakukan pengecekan terhadap kesesuaian kuantitas dan kondisi barang yang diterima. Jika kuantitas dan kondisi barang yang diterima tidak sesuai, maka akan dilakukan pengajuan complain (status invoice berubah menjadi complain) dan ketika complain ditindaklanjuti statusnya berubah menjadi solved. Jika kuantitas dan kondisi barang yang diterima sesuai, maka barang akan diterima Outlet dan status invoice berubah menjadi received. Selanjutnya, Outlet akan melakukan 
pembayaran kepada Central Kitchen (status berubah menjadi paid), jika pembayaran diterima maka Central Kitchen akan mengirim receipt dan status invoice berubah menjadi close yang menandakan siklus telah selesai. Jika pembayaran belum diterima, status invoice berubah menjadi received dan harus melewati tahap pembayaran jika ingin menyelesaikan satu siklus.

\section{Skema Database}

Skema basis data (Database) yang tertera pada Error! Reference source not found. menggambarkan tabel-tabel beserta field yang akan digunakan dalam pembangunan sistem informasi. Gambar tersebut juga memberikan informasi mengenai Primary Key dan Foreign Key untuk setiap tabel yang akan digunakan dalam basis data.

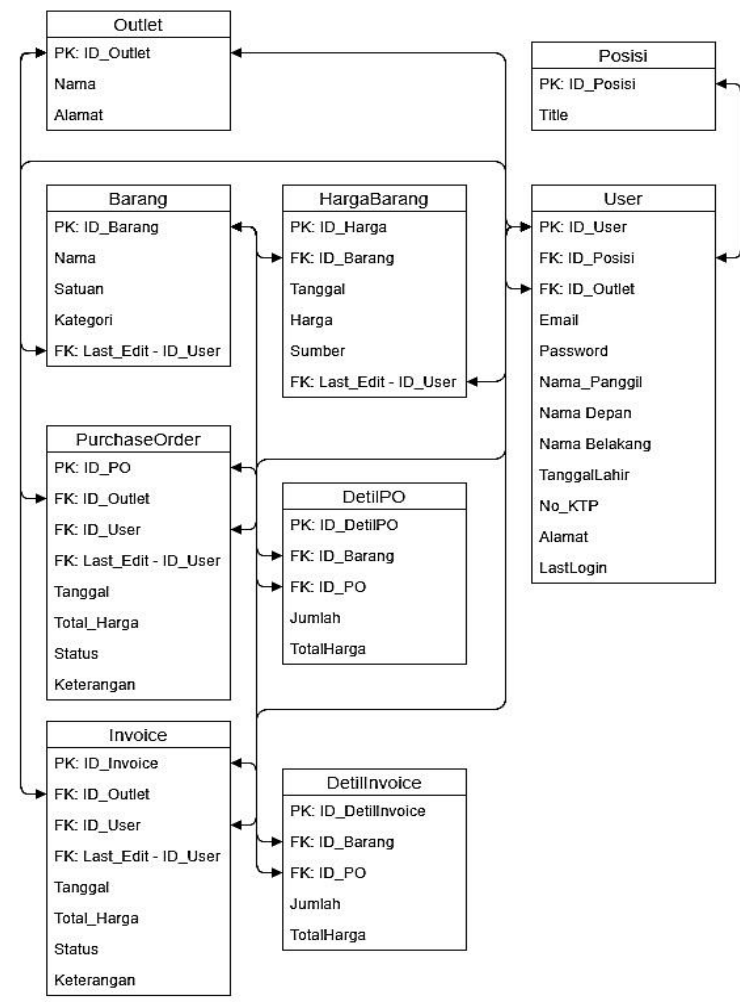

Gambar 6. Skema Database

\subsection{Implementasi Sistem Informasi}

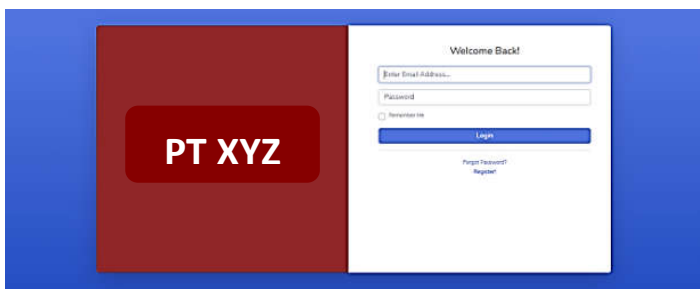

\section{Gambar 6. Tampilan Login}

Tampilan Login yang berguna untuk keamanan dan pemisahan akses terhadap fungsi-fungsi di dalam sistem informasi dapat dilihat pada Gambar $\underline{6}$. User dapat memasukkan data Email dan Password untuk dapat mengakses sistem informasi. Setelah Email dan Password dipastikan benar maka User dapat klik "Login". Ketika data yang dimasukkan benar, maka akan muncul tampilan Dashboard seperti pada Gambar 8. Namun jika data yang dimasukkan salah maka akan diberi peringatan bahwa Login tidak berhasil. Nomor KTP, Tanggal Lahir, dan Alamat Tempat Tinggal.

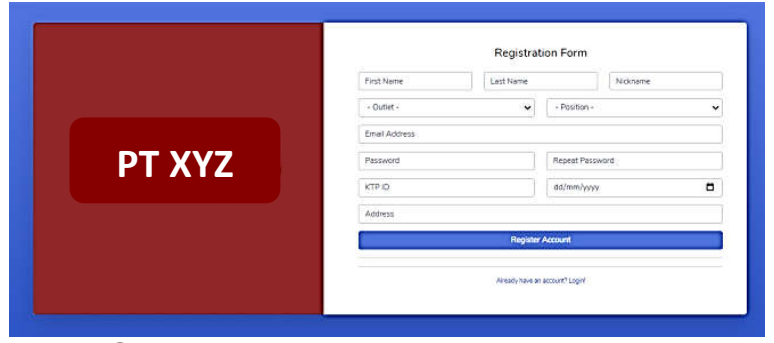

Gambar 7. Tampilan Registrasi User

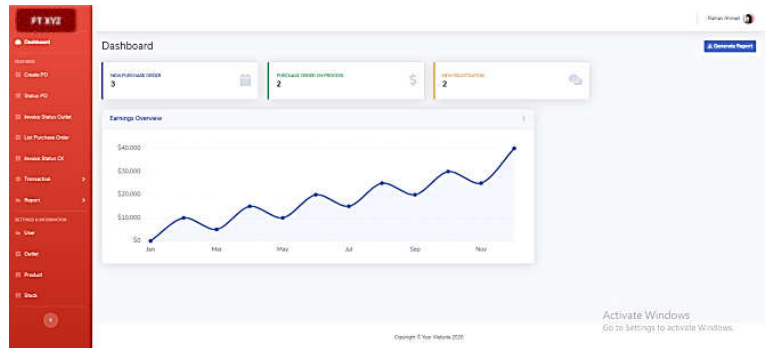

Gambar 8. Tampilan Dashboard

Tampilan dashboard untuk memberikan informasi-informasi utama dalam sistem informasi dapat dilihat pada Gambar 8. Informasi yang dapat dilihat adalah jumlah Purchase Order yang menunggu untuk diproses, jumlah Purchase Order yang sedang diproses, jumlah User yang baru melakukan registrasi, serta pengeluaran bulanan untuk proses Purchase Order.
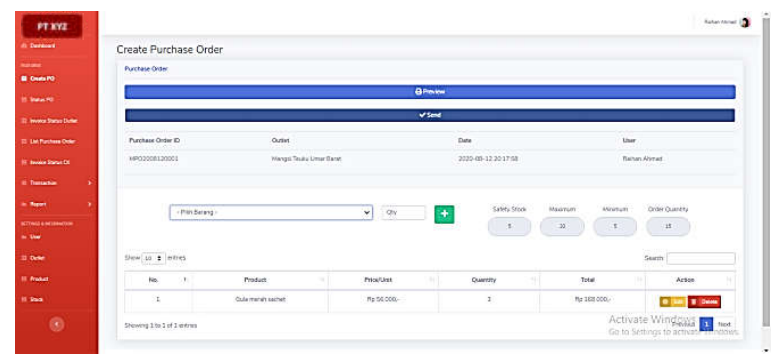

Gambar 9. Create Purchase Order 
Tampilan yang akan dijumpai User di Outlet ketika akan membuat sebuah Purchase Order dapat dilihat pada Gambar 9. Pada tampilan ini terdapat informasi mengenai ID Purchase Order, Outlet yang melakukan pemesanan, tanggal dan waktu Purchase Order dibuat, dan Nama User yang membuat Purchase Order tersebut. Selanjutnya User dapat melakukan pemilihan barang yang akan diorder beserta kuantitasnya, lalu klik tombol berlambang "+", dan barang tersebut akan masuk ke dalam List barang-barang yang dipesan.

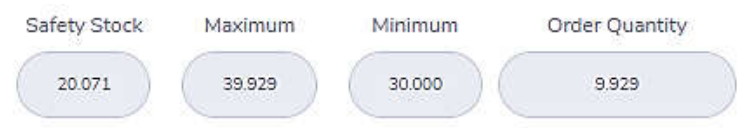

Gambar 10. Min-Max Stock untuk Chicken Boneless Marinasi

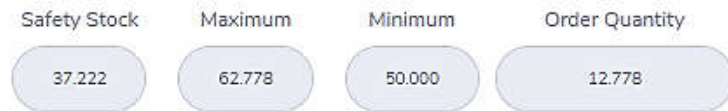

Gambar 11. Min-Max Stock untuk Beef Santori Tenderloin

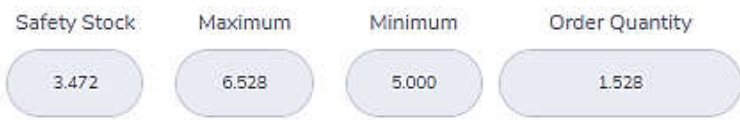

Gambar 12. Min-Max Stock untuk Coffee Bean

Selain itu pada halaman pembuatan Purchase Order ini diterapkan Metode Min-Max Stock yang memberikan informasi Safety Stock, Maximum Stock, Minimum Stock, dan Order Quantity berdasarkan data historis yang telah tercatat dalam sistem. Informasi tersebut berguna untuk memberikan referensi kepada User untuk menentukan berapa jumlah yang perlu diorder untuk menjaga persediaan barang di gudang. Gambar 10, Gambar 11, Gambar 12 merupakan tampilan informasi Min-Max Stock yang dikeluarkan oleh sistem informasi ini.

\subsection{Pengujian Sistem Informasi}

Hasil pengujian yang dilakukan dengan metode Black Box Testing dapat dilihat pada Lampiran. Black Box Testing adalah teknik pengujian dengan menguji setiap fungsi pada sistem informasi dengan requirement/kebutuhan fungsional yang telah direncanakan [14]. Hasil pengujian menunjukkan seluruh fungsi yang tertera dalam requirement dapat berjalan dengan baik sesuai dengan rancangan yang telah dibuat. Terutama fungsi pengelolaan persediaan dan pencatatan terintegrasi yang menjadi kelebihan dari sistem informasi ini. Kemudahan dalam penggunaan sistem informasi dapat membantu pengguna dalam mengelola perusahaan, sehingga diharapkan dengan penggunaan sistem informasi pengelolaan persediaan ini dapat membantu perusahaan.

\section{KESIMPULAN}

Penerapan Min-Max Stock sebagai metode pengelolaan persediaan efektif untuk diterapkan dan dapat memangkas biaya persediaan di PT $\mathrm{XYZ}$. Untuk barang Chicken Boneless Marinasi, Beef Santori Tenderloin, dan Coffee Bean masing-masing menghasilkan penghematan sebesar $5 \%$ atau Rp 1.610.000, $7 \%$ atau Rp 1.598.031,648, dan $11 \%$ atau $\operatorname{Rp} 2.150 .000$. Hasil pengujian sistem informasi menunjukkan bahwa fungsi-fungsi telah berjalan sesuai dengan rancangan yang dibuat. Hasil dari perancangan dan implementasi sistem informasi pengelolaan persediaan PT XYZ ini dapat membantu dalam melakukan pencatatan dan pengelolaan persediaan secara terintegrasi dan terpusat. Dengan begitu diharapkan dapat menyelesaikan permasalahan-permasalahan persediaan yang kerap muncul di PT XYZ.

\section{REFERENSI}

[1] d. B. P. S. Badan Ekonomi Kreatif, "Data Statistik dan Hasil Survei Ekonomi Kreatif," B. E. Kreatif, Ed., ed. Jakarta, 2018.

[2] A. N. Ramadhan and T. M. Simatupang, "Determining Inventory Management Policy for Perishable Materials in Roemah Keboen Restaurant," Procedia - Social and Behavioral Sciences, vol. 65, pp. 992999, 2012.

[3] D. M. Putri and M. M. Ulkhaq, "Analisis Pengendalian Persediaan Bahan Baku Kertas Duplex 120 Gram dengan Metode Min-Max System Di Pt. Jaya Aflaha, Batam," in 4th Annual Conference in Industrial and System Engineering, Semarang, Indonesia, 2017.

[4] T. Tanizaki, T. Hoshino, T. Shimmura, and T. Takenaka, "Demand forecasting in restaurants using machine learning and statistical analysis," in Procedia Conference on Intelligent Computation in Manufacturing Engineering, Gulf of Naples, Italy, 2019, pp. 679-683.

[5] Y. Simaremare, A. Pribadi, and R. P. Wibowo, "Perancangan dan Pembuatan Aplikasi Manajemen Publikasi IImiah Berbasis Online pada Jurnal SISFO," Jurnal Teknik POMITS, vol. 2, pp. 470475, 2013. 
[6] R. V. Palit, Y. D. Y. Rindengan, and A. S. M. Lumenta, "Rancangan Sistem Informasi Keuangan Gereja Berbasis Web di Jemaat Gmim Bukit Moria Malalayang," Jurnal Teknik Elektro dan Komputer, vol. 4, pp. 1-7, 2015.

[7] A. P. Kinanthi, D. Herlina, and F. A. Mahardika, "Analisis Pengendalian Persediaan Bahan Baku Menggunakan Metode Min-Max (Studi Kasus PT.Djitoe Indonesia Tobacco)," Performa: Media IImiah Teknik Industri, vol. 15, pp. 87-92, 2016.

[8] C. K. Yedida and M. M. Ulkhaq, "Perencanaan Kebutuhan Persediaan Material Bahan Baku Pada CV Endhigra Prima dengan Metode Min-Max," Industrial Enginerering Online Journal, vol. 6, 2017.

[9] M. R. Perkasa, R. Kridalukmana, and E. D. Widianto, "Perancangan Sistem Manajemen Restoran dengan Aplikasi Pemesanan Restoran Berbasis Mobile dalam Jaringan Lokal," Jurnal Teknologi dan Sistem Komputer, vol. 4, pp. 289-294, 2016.

[10] A. B. Sayuti, A. A. Supianto, and W. Purnomo, "Pengembangan Sistem Informasi Manajemen Akademik Sekolah Menengah Atas (Studi Kasus pada SMA Sejahtera 1 Depok)," Jurnal Pengembangan Teknologi Informasi dan IImu Komputer, vol. 3, pp. 5389-5396, 2019.

[11] S. Kaur, "Comparative Analysis of Software Development Models," International Journal of Engineering Sciences and Research Technology, vol. 6, pp. 611-617, 2017.

[12] A. Alshamrani and A. Bahattab, "A Comparison Between Three SDLC Models Waterfall Model, Spiral Model, and Incremental/Iterative Model " International Journal of Computer Science Issues, vol. 6, pp. 106-111, 2015.

[13] M. A. Bora and V. Nugroho, "Analisis Pengendalian Persediaan Bahan Baku Makanan di Restoran Hotel XXX," Jurnal Industri Kreatif (JIK), vol. 3, pp. 53-62, 2019.
[14] S. Nidhra and J. Dondeti, "Black Box And White Box Testing TEchniques - A Literatur Review," International Journal of Embedded Systems and Applications (IJESA), vol. 2, pp. 29-50, 2012.

\section{Biografi Penulis}

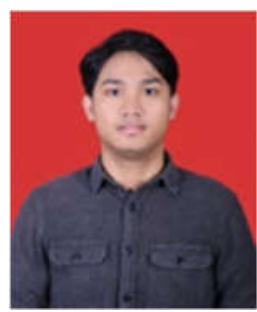

Raihan Ahmad Fadhil

Tercatat sebagai mahasiswa program Sarjana di Program Studi Teknik Logistik, Universitas Pertamina.

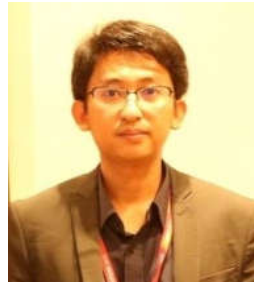

\section{Anak Agung Ngurah} Perwira Redi

Dr. Redi adalah dosen Universitas Bina Nusantara. Berpengalaman sebagai Research Fellow di Monash University, Australia. Memperoleh gelar S2 dan S3 di National Taiwan University of Science and Technology (NTUST).

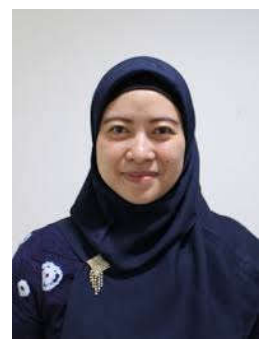

\section{Mirna Lusiani}

Tercatat sebagai dosen tetap Program Studi Teknik Logistik, Universitas

Pertamina.

\section{Lampiran}

\begin{tabular}{|c|c|c|}
\hline No. & Kebutuhan Fungsional & Hasil \\
\hline 1 & $\begin{array}{c}\text { Sistem informasi dapat } \\
\text { memverifikasi pengguna } \\
\text { sebelum penggunaan } \\
\text { sistem. }\end{array}$ & Sesuai \\
\hline 2 & $\begin{array}{l}\text { Sistem Informasi dapat } \\
\text { menampilkan fungsi sesuai } \\
\text { dengan level pengguna. }\end{array}$ & Sesuai \\
\hline 3 & $\begin{array}{c}\text { Manajer Central Kitchen } \\
\text { dapat melihat daftar } \\
\text { purchase order (PO). }\end{array}$ & Sesuai \\
\hline 4 & $\begin{array}{c}\text { Manajer Central Kitchen } \\
\text { dapat melihat data } \\
\text { karyawan. }\end{array}$ & Sesuai \\
\hline 5 & $\begin{array}{c}\text { Manajer Central Kitchen } \\
\text { dapat menambah data } \\
\text { karyawan. }\end{array}$ & Sesuai \\
\hline
\end{tabular}




\begin{tabular}{|c|c|c|c|c|c|}
\hline No. & Kebutuhan Fungsional & Hasil & No. & Kebutuhan Fungsional & Hasil \\
\hline 6 & $\begin{array}{c}\text { Manajer Central Kitchen } \\
\text { dapat mengedit data } \\
\text { karyawan. }\end{array}$ & Sesuai & 26 & $\begin{array}{l}\text { Admin Central Kitchen } \\
\text { dapat mengedit daftar } \\
\text { penerimaan barang. }\end{array}$ & Sesuai \\
\hline 7 & $\begin{array}{l}\text { Manajer Central Kitchen } \\
\text { dapat menghapus hapus } \\
\text { data karyawan. }\end{array}$ & Sesuai & 27 & $\begin{array}{l}\text { Admin Central Kitchen } \\
\text { dapat menghapus daftar } \\
\text { penerimaan barang. }\end{array}$ & Sesuai \\
\hline 8 & $\begin{array}{l}\text { Manajer Central Kitchen } \\
\text { dapat melihat daftar }\end{array}$ & Sesuai & 28 & $\begin{array}{l}\text { Admin Central Kitchen } \\
\text { dapat melihat data barang. }\end{array}$ & Sesuai \\
\hline 9 & $\begin{array}{l}\text { penerimaan barang. } \\
\text { Manajer Central Kitchen } \\
\text { dapat menambah daftar }\end{array}$ & Sesuai & 29 & $\begin{array}{l}\text { Admin Central Kitchen } \\
\text { dapat menambah data } \\
\text { barang. }\end{array}$ & Sesuai \\
\hline 10 & $\begin{array}{l}\text { penerimaan barang. } \\
\text { Manajer Central Kitchen } \\
\text { dapat mengedit daftar }\end{array}$ & Sesuai & 30 & $\begin{array}{c}\text { Admin Central Kitchen } \\
\text { dapat mengedit data } \\
\text { barang. }\end{array}$ & Sesuai \\
\hline 11 & $\begin{array}{l}\text { penerimaan barang. } \\
\text { Manajer Central Kitchen } \\
\text { dapat menghapus daftar }\end{array}$ & Sesuai & 31 & $\begin{array}{c}\text { Admin Central Kitchen } \\
\text { dapat menghapus data } \\
\text { barang. }\end{array}$ & Sesuai \\
\hline 12 & $\begin{array}{l}\text { Manajer Central Kitchen } \\
\text { dapat melihat data barang. }\end{array}$ & Sesuai & 32 & $\begin{array}{c}\text { Admin Outlet dapat melihat } \\
\text { data barang yang tersedia } \\
\text { di Central Kitchen. }\end{array}$ & Sesuai \\
\hline 13 & $\begin{array}{c}\text { Manajer Central Kitchen } \\
\text { dapat menambah data } \\
\text { barang. } \\
\text { Manajer Central Kitchen }\end{array}$ & Sesuai & 33 & $\begin{array}{c}\text { Admin Outlet dapat } \\
\text { melakukan pemesanan } \\
\text { dengan membuat purchase } \\
\text { order (PO). }\end{array}$ & Sesuai \\
\hline & $\begin{array}{c}\text { dapat mengedit data } \\
\text { barang. }\end{array}$ & & 34 & $\begin{array}{l}\text { Staf Central Kitchen dapat } \\
\text { melihat daftar purchase }\end{array}$ & Sesuai \\
\hline 15 & $\begin{array}{c}\text { Manajer Central Kitchen } \\
\text { dapat menghapus data } \\
\text { barang. }\end{array}$ & Sesuai & 35 & $\begin{array}{l}\text { order (PO). } \\
\text { Staf Central Kitchen dapat } \\
\text { membuat invoice. }\end{array}$ & Sesuai \\
\hline 16 & $\begin{array}{l}\text { Manajer Central Kitchen } \\
\text { dapat melihat riwayat }\end{array}$ & Sesuai & 36 & $\begin{array}{l}\text { Staf Central Kitchen dapat } \\
\text { mencetak invoice. }\end{array}$ & Sesuai \\
\hline 17 & $\begin{array}{l}\text { keuangan. } \\
\text { Manajer Central Kitchen } \\
\text { dapat melihat laporan. }\end{array}$ & Sesuai & 37 & $\begin{array}{c}\text { Staf Central Kitchen dapat } \\
\text { melihat daftar penerimaan } \\
\text { barang. }\end{array}$ & Sesuai \\
\hline 18 & $\begin{array}{l}\text { Manajer Central Kitchen } \\
\text { dapat mencetak laporan. }\end{array}$ & Sesuai & 38 & $\begin{array}{l}\text { Staf Central Kitchen dapat } \\
\text { menambah daftar }\end{array}$ & Sesuai \\
\hline 19 & $\begin{array}{l}\text { Manajer Outlet dapat } \\
\text { melihat data barang yang } \\
\text { tersedia di Central Kitchen. }\end{array}$ & Sesuai & 39 & $\begin{array}{l}\text { penerimaan barang. } \\
\text { Staf Central Kitchen dapat } \\
\text { mengedit daftar }\end{array}$ & Sesuai \\
\hline 20 & $\begin{array}{c}\text { Manajer Outlet dapat } \\
\text { melakukan pemesanan } \\
\text { dengan membuat purchase } \\
\text { order (PO). }\end{array}$ & Sesuai & 40 & $\begin{array}{l}\text { penerimaan barang. } \\
\text { Staf Central Kitchen dapat } \\
\text { menghapus daftar } \\
\text { penerimaan barang. }\end{array}$ & Sesuai \\
\hline 21 & $\begin{array}{l}\text { Admin Central Kitchen } \\
\text { dapat melihat daftar }\end{array}$ & Sesuai & 41 & $\begin{array}{l}\text { Staf Central Kitchen dapat } \\
\text { melihat data barang. }\end{array}$ & Sesuai \\
\hline 22 & $\begin{array}{l}\text { purchase order (PO). } \\
\text { Admin Central Kitchen }\end{array}$ & Sesuai & 42 & $\begin{array}{l}\text { Staf Central Kitchen dapat } \\
\text { menambah data barang. }\end{array}$ & Sesuai \\
\hline 23 & $\begin{array}{l}\text { dapat membuat invoice. } \\
\text { Admin Central Kitchen }\end{array}$ & Sesuai & 43 & $\begin{array}{l}\text { Staf Central Kitchen dapat } \\
\text { mengedit data barang. }\end{array}$ & Sesuai \\
\hline 24 & $\begin{array}{l}\text { dapat mencetak invoice. } \\
\text { Admin Central Kitchen }\end{array}$ & Sesuai & 44 & $\begin{array}{l}\text { Staf Central Kitchen dapat } \\
\text { menghapus data barang. }\end{array}$ & Sesuai \\
\hline & $\begin{array}{l}\text { dapat melihat daftar } \\
\text { penerimaan barang. }\end{array}$ & & 45 & $\begin{array}{l}\text { Staf Outlet dapat melihat } \\
\text { data barang yang tersedia }\end{array}$ & Sesuai \\
\hline 25 & $\begin{array}{l}\text { Admin Central Kitchen } \\
\text { dapat menambah daftar }\end{array}$ & Sesuai & 46 & di Central Kitchen. & \\
\hline
\end{tabular}

